\title{
Institutional conditions for socio-economic development in Russian regions
}

\author{
D. Yu. Fraymovich $\bowtie$, M. A. Gundorova \\ Vladimir State University n.a. Alexander and Nikolay Stoletovs, Vladimir, Russia; e-mail:fdu78@rambler.ru
}

\begin{abstract}
The paper describes the results of quantitative analysis of institutional conditions in Russian federal districts. The research methodology relies on a set of indicators applied to evaluate the cultural, legal, business, innovation, and investment-related aspects of institutional environment. The methodological framework also includes a system of criteria (spatial and temporal), which is used to study the indicators and calculate their mean values, dynamic indicators and variability. The parameters were normalized to allow for a more accurate comparison of Russian regions. The findings are presented in the form of tables and a cluster dendrogram, which shows the distribution of Russian federal districts according to different characteristics of their institutional environment. Russian federal districts can be roughly divided into two groups: those with more or less balanced institutional conditions and those with anomalously high or low indicator values. It was found that in some regional socio-economic systems the institutional conditions were favourable for innovation and development although not all the constituent territories enjoyed equal access to these resources, which is supported by the evidence - the regional variability level was high in the corresponding indicators. The methodology and results may be used by research organizations in their analytical work; by education institutions for student training in the sphere of mass data processing; and by the relevant departments of regional and local administrations to design, adjust, and monitor strategic programs for socio-economic development. The proposed methodology, including the set of indicators used, can be adjusted and perfected for other research objectives.
\end{abstract}

\section{KEYWORDS}

institutional conditions; federal districts; average results; dynamics; variability

\section{FOR CITATION}

Fraymovich, D. Yu., \& Gundorova, M. A. (2019) Institutional conditions for socio-economic development in Russian regions.

R-economy, 5(1), 5-12. doi:

10.15826/recon.2019.5.1.001

\section{Оценка институциональных условий воспроизводственного развития территорий России}

\section{Д. Ю. Фраймович $\bowtie$, М. А. Гундорова \\ Владимирский государственньй университет имени Александра Григорьевича и Николая Григорьевича Столетовых, Владимир, Россия; e-mail:fdu78@rambler.ru}

\section{АННОТАЦИЯ}

Цель работы состоит в выполнении количественного анализа сложившихся институциональных условий в федеральных округах России. Рассмотрена методологическая база изучаемой проблемы. Определены ориентиры для проведения дальнейших научных исследований. Представлен авторский перечень индикаторов по оценке уровня развития институтов на территориях, предполагающий диагностику культурных, правовых, предпринимательских, инновационных и инвестиционных факторов. Предложена система критериев для исследования показателей в пространственном и временном измерениях на основе расчета средних результатов, динамических индикаторов и вариативности. В целях корректного сопоставления ряда параметров произведено их нормирование. Использован табличный и графический методы анализа. Сформулированы выводы относительно позиций конкретных территорий по различным показателям. Приведена сводная кластерная дендрограмма, обеспечивающая разделение федеральных округов РФ по комплексу рассматриваемых условий институциональной среды. Выявлена группа территорий с достаточно сбалансированными институциональными, либо близкими к ним позициями, а также ряд федеральных округов, демонстрирующих зачастую крайние (положительные и отрицательные) результаты. Идентифицированы социально-экономические системы с благоприятными инновационно-инвестиционными возможностями, но которые не доступны для всех образующих их территорий, что подтверждает высокая межрегиональная вариативность по соответствующим индикаторам. Методы и результаты исследования могут использоваться: научно-исследовательскими организациями при подготовке аналитических отчетов; учебно-образовательными учреждениями для формирования навыков работы с информационными массивами данных; профильными департаментами территориальных администраций различного уровня при составлении, контроле и корректировке стратегических программ социально-экономического развития. Авторский подход не исключает возможности совершенствования, дополнения и адаптации под конкретные исследовательские задачи.

\section{КЛЮЧЕВЫЕ СЛОВА}

институциональные условия; федеральные округа; средние результаты; динамика; вариативность

\section{ДЛЯ ЦИТИРОВАНИЯ}

Fraymovich, D. Yu., \&

Gundorova, M. A. (2019)

Institutional conditions for socio-economic development in Russian regions.

R-economy, 5(1), 5-12. doi: 10.15826/recon.2019.5.1.001 


\section{Introduction}

The institutional environment in which companies and organizations are embedded, that is, the norms and regulations that shape and constrain their behaviour, has been a subject of active academic debate for quite a long while [1-7]. However, there is a general agreement that these "invisible" institutional forces, which are generated by the legislation and/or stem from the national culture, affect economic performance and resource efficiency on micro-, meso- and macro-levels. In studies considering formal and informal aspects of institutional environment, the focus of attention is often shifted towards quantitative and qualitative evaluation of the impact these aspects have on regional modernization. We believe, however, that the analysis of institutional environment should also include monitoring of the transformation dynamics. We also need to identify the indicators that reveal the specific problems the country faces in certain spheres and suggest ways to tackle these problems.

\section{Theoretical framework}

Institutional environment in different countries and regions can be seen from different perspectives, which may lead us to a wide range of theoretical conclusions as to what constitutes this environment and what role each constituent element plays in socio-economic development of the territory in question. In this context, much attention is usually given to the relationship between the legal, political, business, education, cultural, innovation, investment, environmental and other factors of national and regional economy.

American economist Daron Acemoglu and political scientist James A. Robinson have a clear view on this matter, which is widely discussed nowadays: according to their seminal work Why Nations Fail, economic prosperity, efficient performance and efficient use of resources largely depend upon the inclusiveness of economic institutions. As opposed to inclusive institutions, extractive institutions redistribute wealth to the advantage of elites, which suppresses the development of the private sector and impedes modernization. In the best-case scenario, such institutions are only capable of maintaining catch-up growth within a limited time period, which will eventually lead to a general economic decline [6, p. 12-13; [7].
According to V. L. Tambovtsev, national culture (which is sometimes considered to be equivalent to the national institutional structure) has an impact on the country's economy and its innovative development in particular. In order to formulate recommendations as to what features of national culture should be taken into account when designing and implementing innovation policy, we need comprehensive knowledge as to how these features and modernization are connected. This renders crucial a wide range of methodological considerations, starting from productive operationalization of the term "culture" and its components to accurate interpretation of the results of quantitative analysis [8, p. 84-85]. A substantial contribution was made by a group of Russian researchers, who managed to process statistical and expert data by using 24 indicators on 31 states within a 14-year period (from 2000 to 2013).

Their calculations have shown that a twenty per cent growth in indicators reflecting the development of institutional and infrastructural environment (according to the ranking scale) makes it possible to increase investment efficiency 2-2.5 times. Thus, favourable environment "funds science without spending a dime of public money", that is, it is much more efficient than 'money injections' from the state budget. On the other hand, some countries (including Russia, Poland, Turkey, and Slovakia) face the situation when the state fails to develop the spheres of research and innovation as the allocated funds simply do not bring about any progress and the result is zero growth $[9$, p. $77-83]$.

There are several econometric models to support the hypothesis that institutional factors affect business activity in Russian regions, such as, for example, the model developed by the RANEPA research team. The quantitative evidence they have obtained shows the following:

1) business activity tends to be lower in regions with higher social, environmental, financial and other investment risks;

2) in regions where the legal environment is unfavourable (money laundering, tax evasion, debt evasion, illegal business practices), business activity rates are also lower;

3) in regions with developed banking systems and higher availability of funding for businesses and start-ups (business grants, loan schemes and so on), business activity is generally higher [10, p. 103-112]. 


\section{Research methodology}

In order to evaluate institutional conditions in specific regions, we are going to use a set of indicators that characterize their institutional environment, which is either conducive to productive entrepreneurship and economic growth or not.

The set of indicators to be considered in this study includes the following:

1) the cultural component (hereinafter referred to as "culture"), that is, the number of theatre-goers per 1,000 residents;

2 ) the crime rate, that is, the number of registered crimes per 100,000 residents;

3) the small business turnover (hereinafter "small business") per capita (million roubles per capita);

4) the volume of innovative products (hereinafter "innovation"), that is, the number of innovative products and services in monetary terms per capita (thousand roubles per capita);

5) the volume of investment (hereinafter "investment") or the amount of fixed capital investment per capita (roubles per capita).

It should be noted that the above-described indicators are relative, which makes our calculations more objective and our comparisons more accurate. Thus, we will be able to distinguish between the regions which demonstrate the results that can be considered as "average" and those that have "anomalous" results in absolute terms.

Our analysis covers all Russian federal districts and relies on the official data for an 8-year period (2010-2017) published in Rosstat's statistical yearbooks Regions of Russia. Socio-Economic Indicators and Small and Medium-Sized Businesses in Russia ${ }^{1}$.

For each of the indicators (i) we need to identify the spatial characteristics of specific federal districts $(j)$ and the dynamic changes that occurred in these districts. To do this, we are going to apply the following criteria:

a) mean value (result) $\overline{\operatorname{Ins}}_{i, j}$ in the form of a simple arithmetic mean within the given period of time;

b) dynamic indicator $D_{i j}$, which can be calculated as the ratio of the mean absolute difference of values to the arithmetic mean of the data sam-

${ }^{1}$ Regions of Russia. Socio-Economic Indicators. 2018. Moscow: Rosstat, 2018; Regions of Russia. Socio-Economic Indicators. 2017. Moscow: Rosstat, 2017; Regions of Russia. Socio-Economic Indicators. 2015. Moscow: Rosstat, 2015; Regions of Russia. Socio-Economic Indicators. 2013. Moscow: Rosstat, 2013; Small and Medium-Sized Businesses in Russia. 2012. Moscow: Rosstat, 2012. ple in the $j^{\text {th }}$ territory for the given time period (1a):

$$
D_{i J}=\frac{\bar{\partial}_{i, J}}{\overline{I n s}_{i, j}} \cdot 100 \%,
$$

where $\bar{\partial}_{i, J}$ is the mean absolute difference of indicators, which should be assessed the following way (1b):

$$
\bar{\partial}_{i, J}=\sum \frac{\operatorname{In} s_{i, j, t}-\operatorname{Ins} s_{i, j, t-1}}{n-1},
$$

where $t=1 \ldots n$ are the time periods (years).

We assessed the dynamics of institutional environment $D$ by looking at the changes in the indicator values $(i)$ against the mean values for the given territories $(j)$. A positive and comparatively high value in this or that criterion (as compared to other socio-economic systems) is interpreted as a sign of accelerated development [11, p. 71].

c) regional variability of results $[12$, p. 43-44] $v_{i j}$ in the reporting period (2017) (Formula (2)):

$$
v_{i j}=\frac{s_{i j}}{\overline{\operatorname{Ins}} s_{i, j}},
$$

where $s_{i j}$ is the mean-square deviation of the indicators $(i)$ characterizing the institutional environment in the constituent territories of the $j^{\text {th }}$ federal district.

The indicator set comprises three groups of indicators which we will use to analyze institutional environment in different Russian regions.

\section{Results}

Considering the mean values of the socio-economic development indicators we have chosen for our analysis, it should be noted that all the final values, despite their relative character, are measured in different units. Therefore, for an accurate comparison, we need to normalize the parameters by comparing the normalized values with the actual values and reference values. The above-described algorithm is also applied in the cases when an increase in a certain indicator $(1,3-5)$ will signify an improvement of the situation. In the opposite case (criterion $2-$ crime rate) we are going to calculate the ratio of the minimal result to each of the actual values in the sample of federal districts (Table 1).

The optimal values in Table 1 are given in bold italics. As we can see from the table, none of the Russian federal districts is ahead of the others in more than one of the given parameters. For instance, while the North-Western Federal 
District has managed to maintain its cultural traditions with the average result of 352.88 (the number of theatre-goers per 1,000 residents), the North-Caucasian Federal District has the lowest crime rate -757.75 (the number of crimes per 100,000 residents). At the same time this region lags behind in all the other parameters.

Normalized values characterizing institutional environment in Russian districts is illustrated by the following radar chart (see Figure 1).
Furthermore, it should be emphasized that indicators 1 and 3, corresponding to cultural and business activity, are closely connected, which is shown by the correlation coefficient $r=0.867$.

If we look at the general dynamics of the institutional structure in Russian regions, we can see that the Central Federal District is the most prosperous as it has the highest values in small business development (16.35\%) and investment (8.83\%) (Table 2).

Table 1

Actual mean values (AMV) and normalized mean values (NMV) of indicators characterizing institutional environment in Russian federal districts, 2010-2017

\begin{tabular}{|l|r|r|r|r|r|r|r|r|r|r|}
\hline \multirow{2}{*}{ Federal district } & \multicolumn{2}{|c|}{ Culture } & \multicolumn{2}{|c|}{ Crime } & \multicolumn{2}{c|}{ Small business } & \multicolumn{2}{c|}{ Innovation } & \multicolumn{2}{|c|}{ Investment } \\
\cline { 2 - 12 } & \multicolumn{1}{|c|}{ AMV } & \multicolumn{1}{|c|}{ NMV } & \multicolumn{1}{|c|}{ AMV } & NMV & AMV & NMV & AMV & NMV & AMV & NMV \\
\hline Central & 306.63 & 0.87 & 1379.50 & 0.55 & $\mathbf{0 . 3 1}$ & $\mathbf{1 . 0 0}$ & 23.32 & 0.68 & 83496.25 & 0.46 \\
\hline North-Western & $\mathbf{3 5 2 . 8 8}$ & $\mathbf{1 . 0 0}$ & 1523.50 & 0.50 & 0.28 & 0.89 & 19.62 & 0.57 & 107222.50 & 0.59 \\
\hline Southern & 145.00 & 0.41 & 1355.88 & 0.56 & 0.15 & 0.49 & 6.26 & 0.18 & 82692.38 & 0.45 \\
\hline North-Caucasian & 107.88 & 0.31 & $\mathbf{7 5 7 . 7 5}$ & $\mathbf{1 . 0 0}$ & 0.07 & 0.23 & 2.89 & 0.08 & 45095.00 & 0.25 \\
\hline Volga & 233.50 & 0.66 & 1503.25 & 0.50 & 0.17 & 0.54 & 31.92 & 0.93 & 72108.38 & 0.40 \\
\hline Ural & 224.13 & 0.64 & 1885.75 & 0.40 & 0.21 & 0.68 & 15.10 & 0.44 & $\mathbf{1 8 1 9 3 5 . 3 8}$ & $\mathbf{1 . 0 0}$ \\
\hline Siberian & 255.75 & 0.72 & 2106.38 & 0.36 & 0.16 & 0.52 & 6.89 & 0.20 & 70828.75 & 0.39 \\
\hline Far Eastern & 208.00 & 0.59 & 2081.00 & 0.36 & 0.21 & 0.67 & $\mathbf{3 4 . 3 4}$ & $\mathbf{1 . 0 0}$ & 152417.38 & 0.84 \\
\hline
\end{tabular}

Calculated on the basis of Rosstat data.

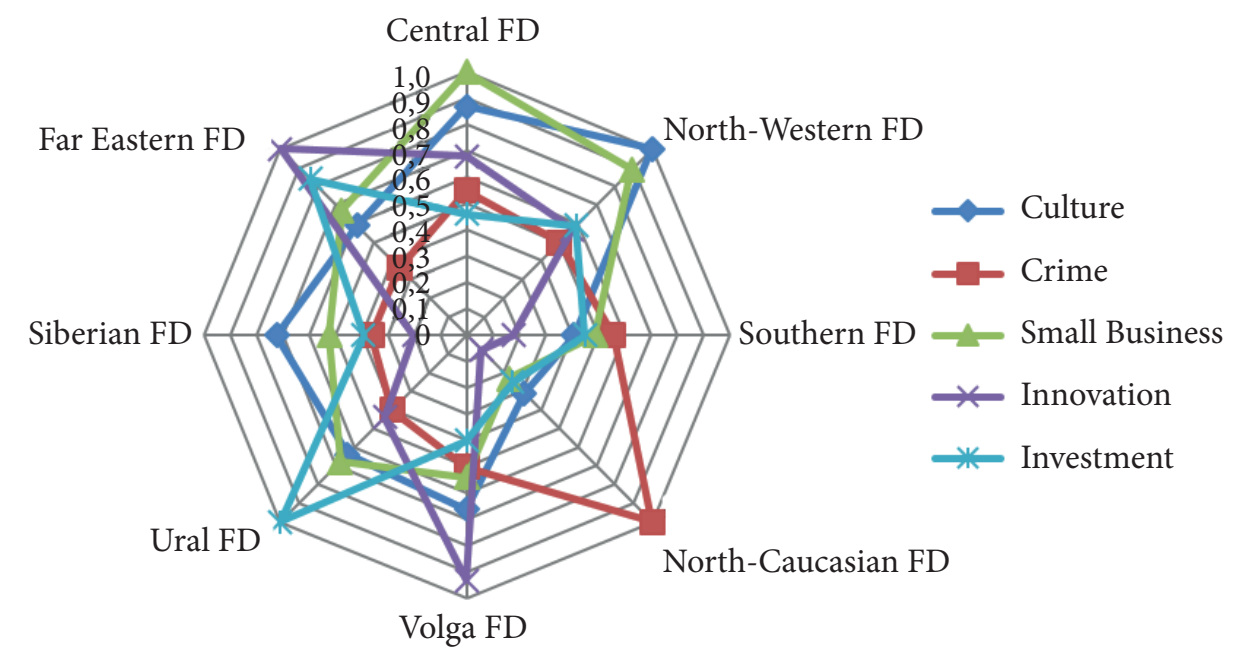

Figure 1. Normalized mean values of the institutional environment indicators in Russian federal districts, 2010-2017 (compiled on the basis of the data shown in Table 1)

Table 2

Dynamics of institutional environment indicators in federal districts of Russia, 2010-2017, \%

\begin{tabular}{|l|r|r|r|r|r|}
\hline \multicolumn{1}{|c|}{ Federal district } & \multicolumn{1}{c|}{ Culture } & \multicolumn{1}{c|}{ Crime } & Small business & Innovation & Investment \\
\hline Central & 5.40 & -4.01 & $\mathbf{1 6 . 3 5}$ & 23.76 & $\mathbf{8 . 8 3}$ \\
\hline North-Western & -4.62 & -3.34 & 12.19 & 13.30 & 6.81 \\
\hline Southern & -35.07 & -1.90 & 12.87 & $\mathbf{3 1 . 7 2}$ & \\
\hline North-Caucasian & $\mathbf{1 6 . 9 5}$ & -1.62 & 12.65 & 15.20 & 15.82 \\
\hline Volga & 10.22 & -4.99 & 10.49 & 19.59 & 6.72 \\
\hline Ural & 5.35 & $-\mathbf{5 . 5 7}$ & 10.23 & 19.01 & 6.64 \\
\hline Siberian & 2.23 & -3.32 & 10.01 & 4.39 & 5.63 \\
\hline Far Eastern & -3.37 & -2.73 & 13.41 & 6.77 \\
\hline
\end{tabular}

Calculated on the basis of Rosstat data. 
Indices of regional variability in institutional conditions

Federal districts of Russia, 2017

\begin{tabular}{|c|c|c|c|c|c|}
\hline Federal district & Culture & Crime & Small business & Innovation & Investment \\
\hline Central & 0,53 & 0,21 & 0,72 & 0,84 & 0,43 \\
\hline North-Western & 0,93 & 0,21 & 0,71 & 1,37 & 2,36 \\
\hline Southern & 0,54 & 0,17 & 0,55 & 1,04 & 0,40 \\
\hline North-Caucasian & 0,32 & 0,48 & 0,76 & 2,46 & 0,26 \\
\hline Volga & 0,30 & 0,20 & 0,26 & 0,75 & 0,45 \\
\hline Ural & 0,60 & 0,19 & 0,37 & 1,44 & 1,58 \\
\hline Siberian & 0,35 & 0,28 & 0,64 & 0,89 & 0,50 \\
\hline Far Eastern & 0,56 & 0,19 & 0,44 & 1,42 & 0,78 \\
\hline
\end{tabular}

Calculated on the basis of Rosstat data.

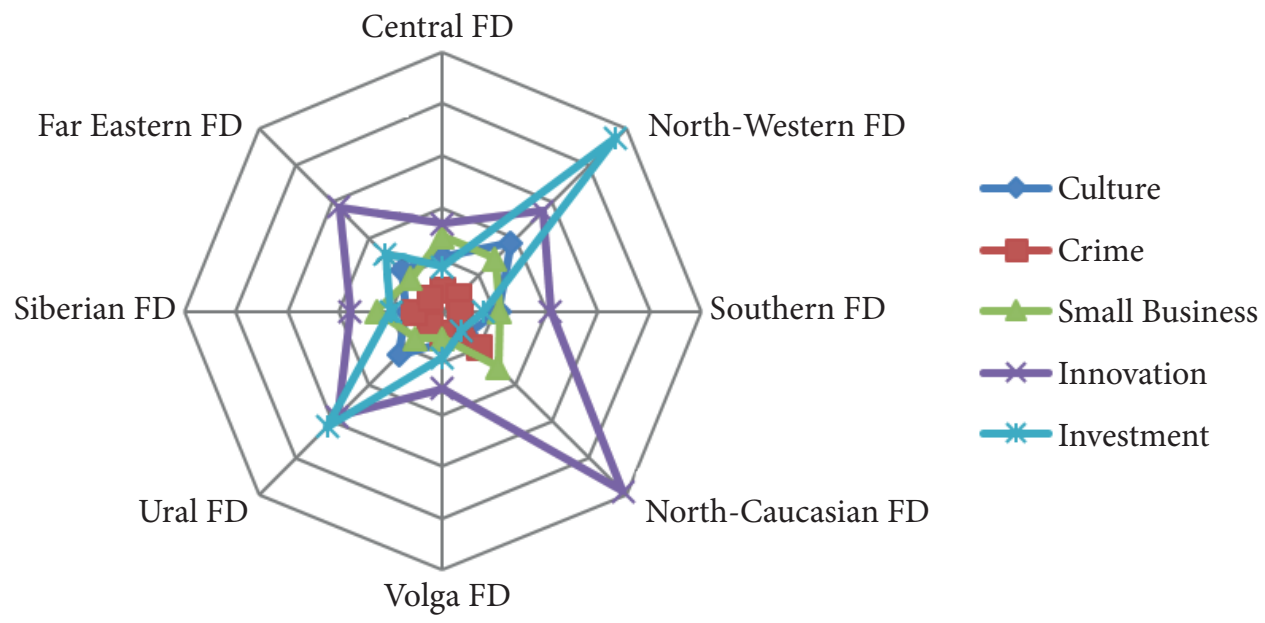

Figure 2. Regional variability of institutional conditions in Russian federal districts, 2017 (compiled on the basis of the data shown in Table 2)

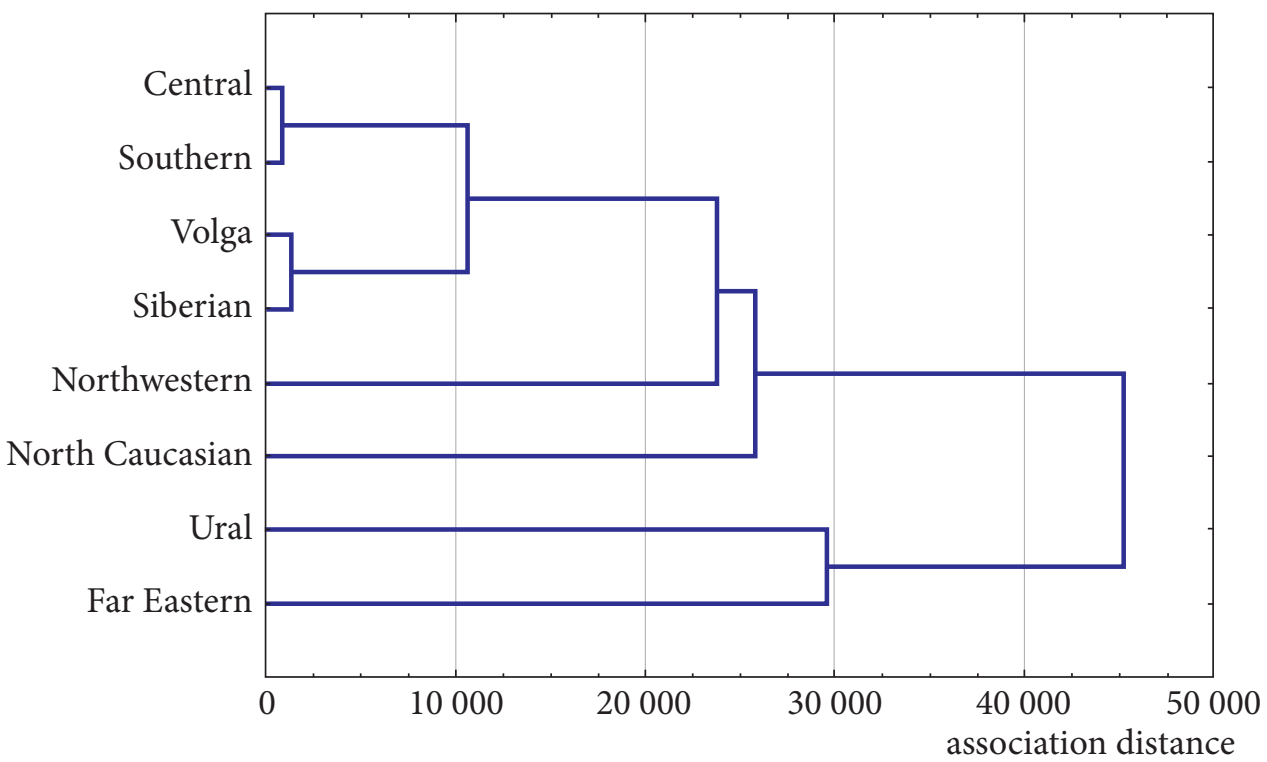

Figure 3. Cluster dendrogram of Russian federal districts according to the institutional environment indicators. We applied single linkage clustering and the Euclidean distance measure (compiled on the basis of the data from Tables 1-3) 
The dynamic component constituting the crime rate (2) should be interpreted by comparing it with the optimal value that corresponds to the maximum crime reduction obtainable on the territory. Therefore, the reference value for this factor is the one reached by the Ural Federal District $(-5.57 \%)$.

Our calculations of regional variability in 2017 have demonstrated that the Volga Federal District has the most balanced situation of all, considering the indicator values of its constituent territories: it has demonstrated optimal results in three categories: culture (1), 0.3; small business (3), 0.26; and innovation (4), 0.75 (Table 3). At the same time, the North Caucasian and North-Western federal districts are lagging behind and have the worst regional imbalance.

As Figure 2 illustrates, the biggest discrepancy lies in the sphere of innovation and investment, which can obviously be detrimental to the development of the small business sector in federal districts.

Figure 3 shows a comprehensive cluster dendrogram of the positions occupied by Russian regions according to the institutional environment indicators.

As Figure 3 shows, the Central, Southern, Volga, and Siberian federal districts enjoy a quite balanced institutional environment. Such federal districts as Northern-Caucasian and North-Western, however, represent a somewhat contradictory picture, combining extreme results, both positive and negative.

The Ural and Far Eastern federal districts have socio-economic systems that are generally favourable for innovation and investment, although not all of their constituent territories enjoy equal access to these resources, which can be seen from the high level of regional variability in the corresponding indicators.

\section{Conclusion}

Our study has shown that there is a high degree of regional variability between different Russian territories and federal districts, each of them having their own individual institutional trajectories. This conclusion is supported by our calculations of the mean and dynamic indicator values and variability coefficients, which show a 2-10 times difference for the factors in question. We found that none of the federal districts seems to be an absolute leader in terms of its socio-economic performance. Moreover, we identified districts which simultaneously demonstrate both the best and the worst results in different parameters characterizing their institutional environment.

Nevertheless, the most balanced situation is in Central, Southern, Volga, and Siberian federal districts, which is supported by the evidence shown in Tables 1-3 and in Figure 3.

Two federal districts - the Ural and Far Eastern - should be considered separately as they generally demonstrate quite high innovation and investment-related indicator values but also have considerable regional variability, which impedes modernization in these regions and in the country as a whole.

Sluggish socio-economic development in the country, especially in the sphere of science, innovation and business, makes it necessary for the academic community to consider a range of factors, which, apart from purely economic reasons, should include institutional conditions and psychological factors leading to the country's unsatisfactory economic performance. These problems are described in detail by N. I. Komkov, who believes that the main reasons for slow decision-making and failure to ensure innovation and modernization in the manufacturing sector are as follows: the personnel of enterprises are not interested in modernization and are enjoying local benefits from adhering to old technologies. Moreover, both the management and the staff of industrial enterprises are aware of the fact that a full or partial suspension of production or service operations necessary to modernize the production facilities would inevitably entail a loss of profit or maybe a loss of the market, too. This may also mean redundancies and other negative consequences. The management of industrial enterprises may also harbour doubts about the potential and efficiency of the new technologies [13, p. 14].

V. M. Polterovich points out that in order to break out of the stagnation trap, the country should address institutional macro-level problems by countering corruption, reducing shadow economy, lifting the administrative barriers, ensuring greater business transparency, protecting private property rights and so on. These goals are, in his opinion, worthy of the effort. The results of such effort, however, are heavily dependent on mass culture and informal norms in the country. In Russia, the latter currently impede any modernization attempts. Meanwhile, coercion and 
control used to enforce the necessary reforms often prove to be cost-inefficient $[14$, p. 96$]$.

G. G. Malinetsky believes that it is necessary to make the public and state authorities more motivated to support innovation, which will inevitably lead to the transformation of those institutions that could foster and enhance innovation in the country. According to Malinetsky, to ensure technological development, we need to establish an innovation-friendly environment and make the economy more sensitive to innovation. This can be accomplished by stimulating a constant flow of ideas, projects, inventions and plans that would at least match the Soviet level (which was 10 times higher than the current level) and enhance scientific, technological, marketing and other expertise. This would reduce investment risk (including the risks faced by the state as an investor), bringing it to an acceptable level. For instance, in Silicon Valley, on average, only 7 projects out of 1,000 are sponsored by venture funds. Russia, however, has a different socio-economic environment characterized by low demand, money shortages, and the lack of lending support for innovative businesses [15, p. 27].

The above-described methods and results can be further used by research organizations in their analytical work; by education institutions for student training in the sphere of mass data processing; and by the relevant departments of regional and local administrations to design, adjust, and monitor strategic programs for socio-economic development. The proposed methodology, including the set of indicators used, can be adjusted and perfected for other research objectives.

\section{References}

1. North, D. (1992). Institutions, ideology, and economic performance. Cato Journal, 11(3), 477-488.

2. Pavlov, K. (2013). Patoinstitutionalism, patoinstitutions and modernization of Russian economy. Problemy teorii i praktiki upravleniya $=$ Theoretical and Practical Aspects of Management, 7, 124-132. (In Russ.)

3. Etzkowitz ,H., Leydesdorff, L. (1995). The triple helix university-industry-government relations. EASST Review, 14(1), 14-19.

4. MacGregor, S. P. \& Carleton, T. (Eds) (2012) Sustaining innovation. Collaboration models for a complex world. New York: Springer Publ.

5. Friedman, M., \& Friedman, R. (1980). Free to choose: a personal statement. New York and London: Harcourt Brace Jovanovich.

6. Natkhov, T. V. \& Polishchuk, L. I. (2017). Political economy of institutions and development: The Importance of Being Inclusive. Reflection on "Why Nations Fail" by D. Acemoglu and J. Robinson. Part II. Institutional Change and Implications for Russia. Journal of the New Economic Association, 3, 12-32. (In Russ.)

7. Acemoglu, D., \& Robinson, J. (2012). Why nations fail. The origins of power, prosperity, and poverty. NY: Crown Business.

8. Tambovtsev, V. L. (2018). Innovations and culture: Importance of the analysis methodology. Voprosy Ekonomiki, 9, 70-94. (In Russ.)

9. Barabash, N. S., Bochkovsky, P. P., \& Shamsutdinov, Yu. A. (2017). Influence of institutional and infrastructure environments on development of innovations in the modern world. Problemy prognozirovaniya, 3, 75-89. (In Russ.)

10. Barinova, V. A., Zemtsov, S. P., \& Tsareva, Yu. V. (2018). Business and institutes: whether there is a communication at the regional level in Russia? Voprosy Ekonomiki, 6, 92-116. (In Russ.)

11. Fraymovich, D. Yu., Gundorova, M. A., \& Mishchenko, Z. V. (2018). Investigation of the efficiency of the development of intangible resources in the territories of the Russian Federation. Public Administration, 20(5), 68-75. (In Russ.)

12. Donichev, O. A., Mishchenko, Z. V., \& Fraymovich, D. Yu. (2011). The system of economic-mathematical indicators in assessment of modernization capacity of regions of the federal district. Financial Analytics: Science and Experience = Finansovaya analitika: problemy i resheniya, 44, 42-49. (In Russ.)

13. Komkov, N. I. (2017). Scientific and technological development: restrictions and opportunities. Problemy prognozirovaniya, 5, 11-21. (In Russ.) 
14. Polterovich, V. M. (2017) Institutes of the catching-up development and civil culture (A report fragment on Abalkinsky readings VEO of Russia). Volnaya ekonomika, 3, 95-99. (In Russ.)

15. Malinetsky, G. G. (2018). Strategic planning, cross-disciplinary approaches and innovative development of Russia. Innovations, 4, 22-28. (In Russ.)

\section{Authors}

Denis Yu. Fraymovich - Professor of Economics, Vladimir State University n.a. Alexander and Nikolay Stoletovs (79 Gorkogo St., Vladimir, 600005, Russia); e-mail: fdu78@rambler.ru.

Marina A. Gundorova - Associate professor of Economics, Vladimir State University n.a. Alexander and Nikolay Stoletovs (79 Gorkogo St., Vladimir, 600005, Russia); e-mail: mg82.82@mail.ru.

ARTICLE INFO: received December 20, 2018; accepted February 11, 2019

\section{Информация об авторах}

Фраймович Денис Юрьевич - доктор экономических наук, доцент, профессор кафедры экономики и управления инвестициями и инновациями, Владимирский государственный университет имени Александра Григорьевича и Николая Григорьевича Столетовых (600000, г. Владимир, ул. Горького, 87); e-mail: fdu78@rambler.ru.

Гундорова Марина Александровна - кандидат экономических наук, доцент кафедры экономики и управления инвестициями и инновациями, Владимирский государственный университет имени Александра Григорьевича и Николая Григорьевича Столетовых (600000, г. Владимир, ул. Горького, 87); e-mail: mg82.82@mail.ru.

ИНФОРМАЦИЯ О СТАТЬЕ: дата поступления 20 декабря 2018 г.; дата принятия к печати 11 февраля 2019 г. 